\title{
INFLUÊNCIA DO TIPO DE EMBALAGEM NA QUALIDADE FISIOLÓGICA DE SEMENTES DE MILHO CRIOULO ${ }^{1}$
}

\author{
LEONARDO MAGALHÃES ANTONELLO², MARLOVE FÁTIMA BRIÃO MUNIZ³, SIMONE CRISTIANE BRAND³, \\ JOHNATHAN RODRIGUES ${ }^{3}$, NILSON LEMOS DE MENEZES ${ }^{2}$, STELA MARIS KULCZYNSKI ${ }^{4}$
}

\begin{abstract}
RESUMO - Objetivou-se com este trabalho avaliar a qualidade fisiológica de sementes de seis variedades de milho submetidas ao armazenamento em embalagens plásticas a vácuo e em sacos de pano. Para tanto, foram realizadas avaliações do teor de água, germinação, primeira contagem de germinação, emergência, índice de velocidade de emergência, comprimento de parte aérea e massa seca de plântulas. Utilizou-se o delineamento inteiramente casualizado, com os tratamentos arranjados em esquema $6 \times 4 \times 2$ (variedades $x$ tempos de armazenamento $x$ embalagens). Durante os seis meses de armazenamento, o teor de água das sementes não ultrapassou os 13\%. A germinação foi reduzida nas duas embalagens, sendo que na embalagem plástica, esta queda ocorreu devido à retirada do oxigênio de dentro da embalagem, enquanto, para as sementes armazenadas em sacos de pano, pela infestação dos insetos-praga e o aumento da incidência de fungos, ocasionado pelas condições ambientais durante o período de armazenamento. Na avaliação de emergência, a tendência foi semelhante. Para o comprimento de parte aérea e massa seca para as duas formas de armazenamento, ao final dos seis meses, observaram-se valores próximos ou superiores à condição inicial. A manutenção da qualidade fisiológica de sementes de milho, durante o armazenamento, depende da variedade e do tipo de embalagem.
\end{abstract}

Termos para indexação: Zea mays L., embalagens plásticas, sacos de pano.

\section{INFLUENCE OF PACKAGING ON PHYSIOLOGICAL QUALITY OF MAIZE SEEDS}

\begin{abstract}
This study aimed to evaluate the physiological quality of maize seeds of six varieties submitted to the storage in plastic packaging and cloth bags. The moisture content, germination, germination first count, emergence, speed emergence rate, length and dry weight of seedlings were evaluated. During the six months of storage, the seed moisture content did not exceed $13 \%$. The germination and emergency was reduced in both packagings, and in the plastic packaging, the reduction was due to the removal of oxygen from inside the package, while for the seeds stored in cloth bags, it was because of infestations of insect pests and increasing incidence of fungi due the ambient conditions during storage. The varieties performed differently regarding the physiological parameters of quality seeds, depending on the packaging used. The length and dry mass in the two types of storage presented values near or above the initial condition at the end of six months. The maintenance of maize seed physiological quality during storage depends on the variety and type of packaging.
\end{abstract}

Index terms: Zea mays L., plastic packaging, cloth bags.

${ }^{1}$ Submetido em 15/12/2008. Aceito para publicação em 30/08/2009.

${ }^{2}$ Departamento de Fitotecnia, Universidade Federal de Santa Maria (UFSM). Avenida Roraima, $\mathrm{n}^{\circ}$. 1000, CEP 97105-900, Bairro Camobi, Santa Maria, RS, Brasil, lmantonello@hotmail.com.
${ }^{3}$ Departamento de Defesa Fitossanitária, Universidade Federal de Santa Maria, Santa Maria, RS, Brasil, marlove@smail.ufsm.br.

${ }^{4}$ Centro de Educação Superior Norte - RS (Cesnors), Departamento de Agronomia, Frederico Westphalen, RS, Brasil. 


\section{INTRODUÇÃO}

O milho está entre os cereais mais cultivados no país, de grande importância econômica e social, ocupando 31\% da área total cultivada na safra 2007/2008 e com 40\% do total da produção de grãos, segundo estimativas da Conab (2008). No país, existe uma ampla variabilidade genética nos materiais disponíveis, sendo o germoplasma do milho constituído de variedades de polinização aberta, selecionadas pelos agricultores (crioulas ou locais), populações adaptadas, híbridos e materiais exóticos introduzidos. As populações "crioulas" são materiais importantes para o melhoramento, pelo elevado potencial de adaptação que apresentam em condições ambientais específicas (Paterniani et al., 2000), e por constituírem fonte de variabilidade genética que podem ser exploradas na busca por genes tolerantes e/ou resistentes aos fatores bióticos e abióticos (Araújo e Nass, 2002). Ainda, são importantes na sobrevivência de pequenos agricultores, como base alimentar na dieta de suas famílias e criações, manutenção da história, cultura e costumes das comunidades e, como fonte de renda.

O uso de sementes de boa qualidade é requisito essencial para o sucesso no estabelecimento dos cultivos e na obtenção de elevados rendimentos. A qualidade das sementes é determinada pela interação entre atributos fisiológicos, sanitários, genéticos e físicos, os quais interferem diretamente no potencial de desempenho em campo e durante o armazenamento (Marcos Filho, 1999).

A qualidade das sementes sofre grande influência das condições nas quais permanecem armazenadas entre a colheita e a semeadura. Segundo Delouche e Baskin (1973), a velocidade de deterioração das sementes é influenciada por fatores genéticos, formas de manipulação e condições de armazenamento. Ao longo do período de armazenamento, a taxa de deterioração das sementes sofre influência de vários fatores, sendo a temperatura e a umidade relativa, geralmente citadas como os mais importantes (Smith e Berjak, 1995), além do tipo de embalagem, que será determinante na taxa de deterioração e, por conseguinte, na manutenção da qualidade fisiológica das sementes.

O conteúdo de água e a temperatura da massa de sementes podem ser facilmente manipulados pelo processo de secagem e de armazenamento em ambiente com umidade e temperatura controladas por equipamentos (Camargo e Carvalho, 2008). Os mesmos autores citam que o conteúdo de oxigênio disponível, por sua vez, pode ser reduzido pelo empacotamento a vácuo, em embalagens impermeáveis seladas, ou pela injeção de um gás livre de oxigênio.
Segundo New (1988), o acondicionamento de semente de soja e milho a vácuo, pode tornar a técnica não recomendável para uso comercial em larga escala, pois pode resultar em ganhos pouco significativos. Dessa forma, faz-se necessário alternativas, que possam ser utilizadas por pequenos produtores, em menor escala.

Diante do exposto, objetivou-se com este trabalho avaliar a qualidade fisiológica de sementes de milho "crioulo" submetidas ao armazenamento em embalagens plásticas a vácuo e em sacos de pano.

\section{MATERIAL E MÉTODOS}

Os experimentos foram realizados no Laboratório Didático de Pesquisa em Sementes e na área experimental do Departamento de Fitotecnia, da Universidade Federal de Santa Maria. Foram avaliados seis lotes de sementes das seguintes variedades de polinização aberta: Caiano, Mato Grosso, Pururuca Branco, Cabo Roxo, Brancão e Bico de Ouro, provenientes do banco de sementes da Associação dos Cultivadores de Milho Crioulo/Guardiões de Semente de Milho Crioulo do município de Ibarama, RS.

As sementes foram separadas em lotes de um quilo e armazenadas em sacos de pano e em embalagens plásticas de dois litros (PET), por um período de 180 dias, sob as condições ambientais do município de Santa Maria, RS, onde o clima, segundo a classificação climática de Köpen, é Cfa, subtropical, com temperatura média do mês mais frio compreendida entre $5^{\circ}$ e $18^{\circ} \mathrm{C}$ e temperatura média do mês mais quente superior a $24{ }^{\circ} \mathrm{C}$. A precipitação média anual é de $1600 \mathrm{~mm}$ e a umidade relativa média é de $85 \%$ (Moreno, 1961).

As sementes armazenadas em embalagens plásticas tiveram o oxigênio, presente dentro das embalagens, eliminado através da queima de um pedaço de algodão embebido em álcool. A qualidade das sementes foi avaliada a cada dois meses, por meio dos seguintes parâmetros: teor de água, determinado pelo método da estufa a $105^{\circ} \mathrm{C}+3{ }^{\circ} \mathrm{C}$, por 24 horas (Brasil, 1992), utilizando-se duas subamostras de $5 \mathrm{~g}$ de sementes para cada lote. Os resultados foram expressos em percentagem.

$O$ teste de germinação foi conduzido com quatro repetições de 50 sementes cada, distribuídas em papel germitest umedecido com água destilada na proporção de 2,5 vezes o peso do papel e então, acondicionadas em câmara climatizada à temperatura $25{ }^{\circ} \mathrm{C}$ e fotoperíodo de 12 horas. As contagens foram realizadas aos quatro e aos sete dias após a semeadura (Brasil, 1992). Os resultados 
foram expressos em percentagem de plântulas normais. Conjuntamente, foi realizada a primeira contagem de germinação, determinando-se a percentagem de plântulas normais obtidas aos quatro dias após a instalação do teste, sendo os dados expressos em percentagem. Para a avaliação da emergência e índice de velocidade de emergência de plântulas foi realizada a semeadura de quatro repetições de 50 sementes, em bandejas alveoladas, utilizando substrato comercial Plantmax ${ }^{\circledR}$. As bandejas foram mantidas em casa de vegetação sob condições não controladas. Foram realizadas avaliações diárias a partir da semeadura, computandose o número de plântulas emersas até a estabilização. Foi determinada a porcentagem de plântulas emersas até o $21^{\circ}$ dia e o índice de velocidade de emergência (IVE), de acordo com a fórmula proposta por Maguire (1962), Após 21 dias, mediu-se o comprimento de parte aérea, com auxílio de régua milimetrada, utilizando-se 10 plântulas normais. $\mathrm{O}$ comprimento médio de parte aérea foi obtido somando-se as medidas de cada repetição e dividindo-se pelo número das plântulas mensuradas, com resultados expressos em centímetros $(\mathrm{cm})$. Após, para determinação da massa seca, as plântulas foram acondicionadas em sacos de papel e levadas à estufa a temperatura de $70^{\circ} \mathrm{C}$, até atingirem massa constante, sendo após pesadas em balança com precisão de $0,001 \mathrm{~g}$ e os resultados expressos em gramas.

Para a análise estatística, utilizou-se o delineamento inteiramente casualizado, com os tratamentos arranjados em esquema $6 \times 4 \times 2$ (variedades $\mathrm{x}$ tempos de armazenamento $\mathrm{x}$ embalagens) com quatro repetições. Os dados das variáveis foram submetidos à análise de variância pelo teste de $\mathrm{F}$ e, quando constatado efeito significativo $(\mathrm{P}<0,05)$, foi realizado o estudo de regressão polinomial. Para as análises, utilizouse o Sistema de Análise Estatística - SANEST (Zonta e Machado, 1984).

\section{RESULTADOS E DISCUSSÃO}

No decorrer do período de armazenamento, a partir da primeira amostragem, verificou-se a presença do gorgulho do milho (Sitophilus zeamais Mot.) (Coleoptera: Curculionidae), identificado de acordo com Prates e Frattini (1976).

$\mathrm{Na}$ avaliação da qualidade fisiológica das variedades de semente de milho, verificou-se interação entre variedades, tempos de armazenamento e embalagens. Durante os seis meses de armazenamento, o teor de água das sementes não ultrapassou os $13 \%$, nas duas embalagens, o que segundo Portella e Eichelberger (2001), não compromete a qualidade das sementes, pois com esta umidade, não ocorre respiração ativa. Segundo Delouche e Baskin (1973), a umidade relativa afeta a qualidade fisiológica das sementes de duas maneiras: seu conteúdo de umidade é função da umidade relativa; e a infestação, o crescimento e a reprodução de fungos e insetos são fortemente influenciados pela umidade relativa do microambiente na massa de sementes. Alto teor de água nas sementes, combinado com altas temperaturas, acelera os processos naturais de degeneração dos sistemas biológicos, de maneira que, sob estas condições, as sementes perdem seu vigor rapidamente e algum tempo depois sua capacidade de germinação (Almeida et al., 1997). A umidade e a temperatura têm grande influência na conservação da semente, influenciando as reações bioquímicas que regulam o metabolismo envolvido no processo (Martins e Lago, 2008), fatores esses que são determinados pela embalagem e condição de armazenamento. Nas condições ambientais de realização do presente estudo, as altas temperaturas, combinadas com alta umidade relativa, podem ter contribuído para o decréscimo dos valores de germinação. Além disso, as embalagens utilizadas são permeáveis e semi-permeáveis e por isso, estão sujeitas à influência das variações das condições ambientais externas, o que pode ocasionar perdas de qualidade das sementes armazenadas.

Nas duas embalagens, para todas as variedades, a germinação foi reduzida de forma significativa durante os seis meses de armazenamento (Figura 1). As sementes armazenadas nas embalagens plásticas mantiveram os percentuais de germinação praticamente sem alteração até o segundo mês de armazenamento e após houve uma queda significativa, chegando a $0 \%$ na variedade Brancão e $60 \%$, $40 \%$ e $30 \%$ nas variedades Caiano, Bico de Ouro e Cabo Roxo, respectivamente (Figura 1), com tendência quadrática. Para as sementes armazenadas em sacos de pano a tendência também foi quadrática, neste caso, causada pela infestação de $S$. zeamais e o aumento da incidência de fungos, observandose, no entanto, germinação de $70 \%$ na variedade Pururuca Branco, na qual foi verificada uma menor incidência de insetos. Para esta mesma variedade, o armazenamento em embalagem plástica reduziu a germinação a 20,5\%. Esses resultados podem ser explicados por diversos fatores, tais como a supressão de oxigênio das embalagens plásticas, que pode ter afetado o metabolismo das sementes a ponto de comprometer sua viabilidade, e para as sementes armazenadas em sacos de pano, além das condições ambientais de alta umidade relativa combinada com altas temperaturas durante o período de armazenamento, a elevada incidência de insetospraga comprometeu a viabilidade, pelos danos ao embrião, e o vigor, pelo consumo de reservas da semente. 
Caiano

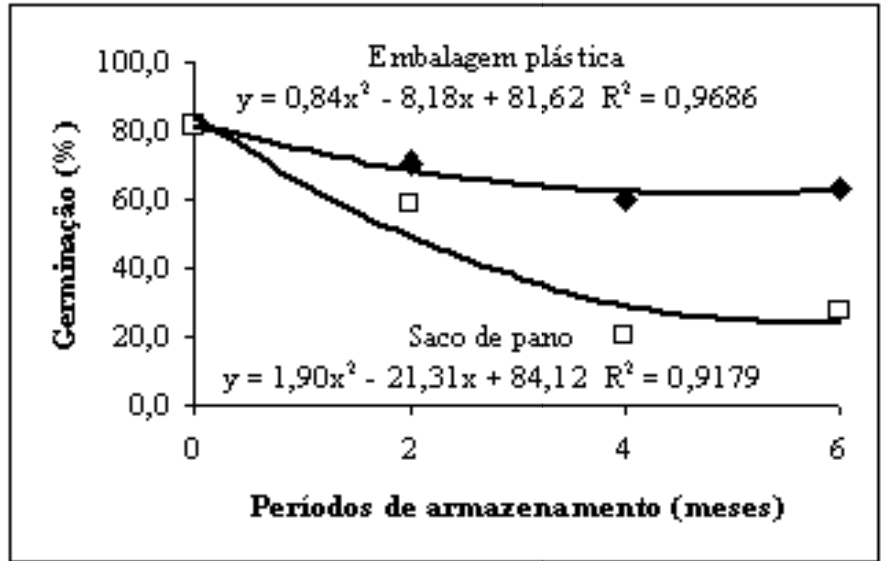

Purduca Branco

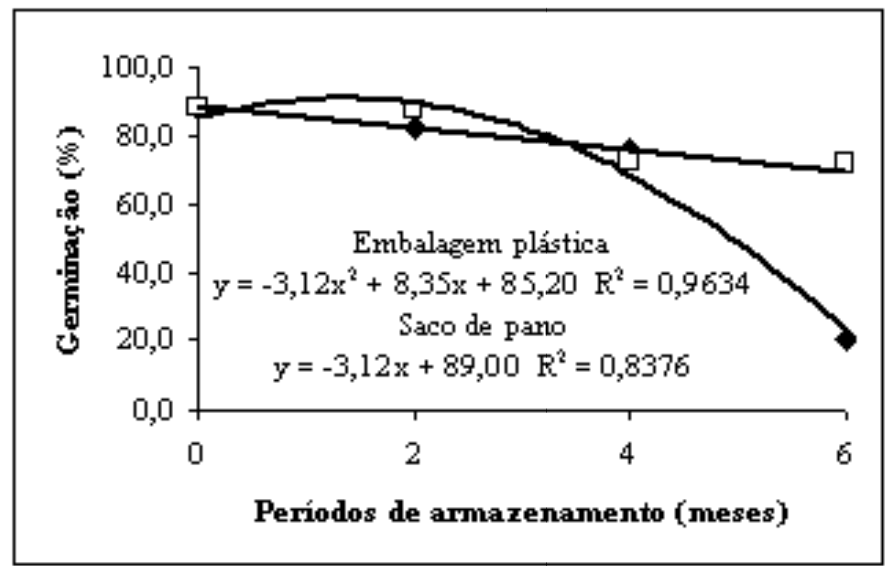

Brancăo

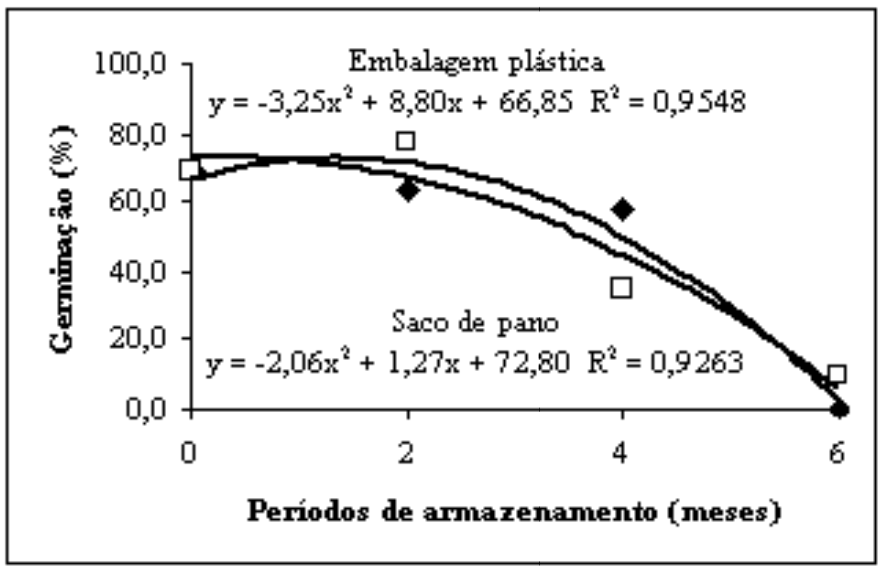

Wat o Grosso

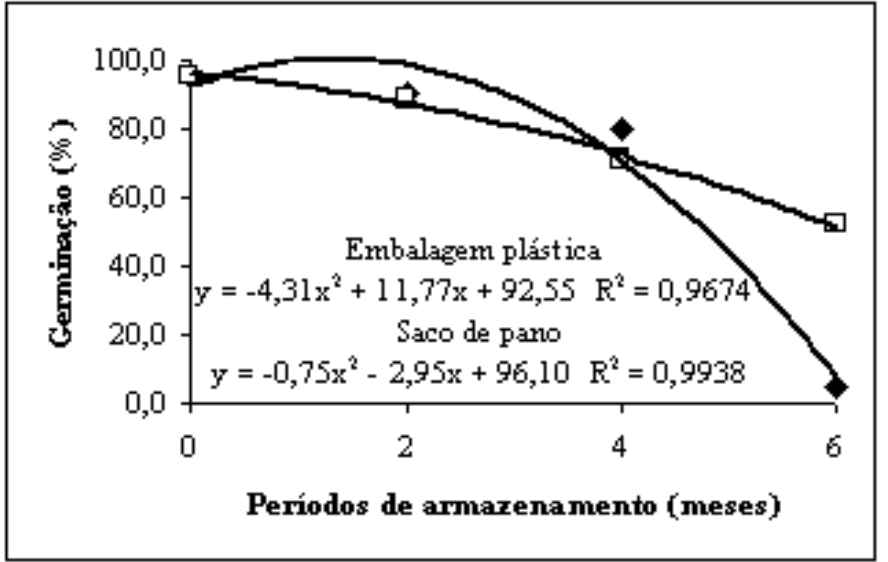

Cabo Roxo

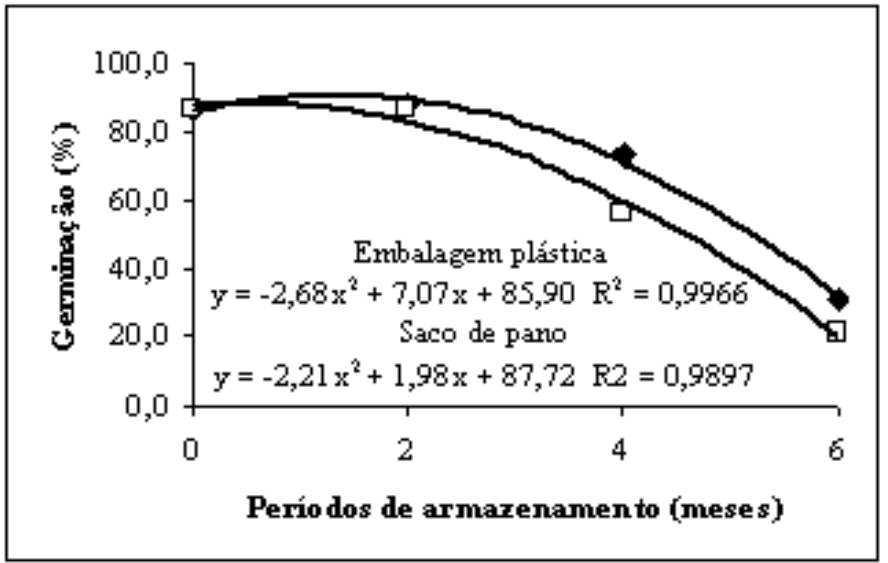

Bico de Ouro

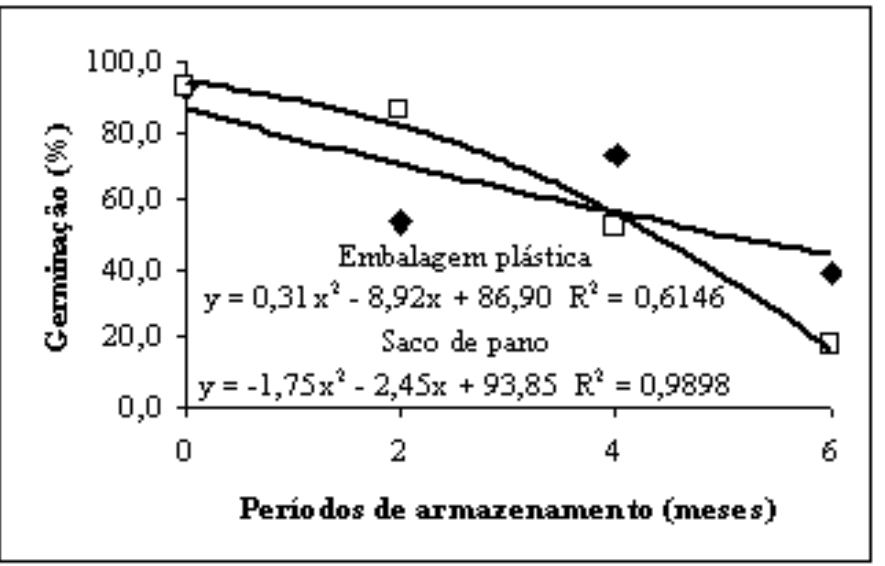

FIGURA 1. Germinação de sementes de milho, variedades Caiano; Mato Grosso; Pururuca Branco; Cabo Roxo; Brancão; Bico de Ouro, acondicionadas em embalagem plástica (४) e em saco de pano ( $\square$ ) e armazenadas por seis meses. 
Outro fator que se deve levar em consideração na queda significativa da germinação para as duas formas de armazenamento é a deterioração natural das sementes, que é um processo irreversível. Porém, é possível retardar sua velocidade através do manejo correto e eficiente das condições ambientais durante o armazenamento (Baudet, 2003), aumentando dessa forma o tempo que a semente permanece viável durante esse período. Esta deterioração causa progressivo aumento do tempo necessário para a obtenção de um estande adequado de plantas (Vieira e Carvalho, 1994).

Os resultados do presente trabalho discordam com os obtidos por Camargo e Carvalho (2008) que, para o armazenamento em condições de ambiente natural, o acondicionamento a vácuo ou em embalagem plástica assegurou menores reduções na qualidade fisiológica de sementes de milho doce, após 18 meses. Marincek (2000) não verificou queda na germinação de sementes de milho, armazenadas por 12 meses em ambiente natural, porém ressalta que as condições ambientais durante o armazenamento são determinantes para a manutenção da qualidade das sementes de milho.

$\mathrm{Na}$ avaliação da primeira contagem de germinação (Figura 2), o modelo ajustado foi quadrático, com queda, de maneira geral, para as duas formas de armazenamento, a partir da segunda avaliação, devido à deterioração das sementes armazenadas na embalagem plástica e pelo consumo de reservas ocasionado pelos insetos, no saco de pano, para a maioria das variedades estudadas.

$\mathrm{Na}$ avaliação de emergência para as sementes armazenadas em embalagens plásticas (Figura 3), o comportamento das variedades foi semelhante à observada na germinação, com os maiores valores observados para Caiano (77\%) e Bico de Ouro (65\%) e Cabo Roxo (64\%). Nas demais, a emergência foi reduzida drasticamente chegando à zero na variedade Brancão. Já para o armazenamento em sacos de pano, a variedade que demonstrou menor redução na emergência de plântulas foi Pururuca Branco (73\%), seguida pela Mato Grosso (65\%). As variedades que apresentaram redução mais significativa na emergência foram Caiano (38\%) e Bico de Ouro (36\%). Bilia et al. (1994), ao armazenarem sementes de milho em câmara seca, câmara fria e condição ambiente não verificaram diferença com relação à emergência de plântulas à campo, sendo esta superior aos $90 \%$ para as três condições, ao final dos seis meses de avaliação. Na avaliação do índice de velocidade de emergência (IVE) (Figura 4), para as sementes armazenadas em embalagens plásticas, as variedades Caiano, Cabo Roxo e Bico de Ouro apresentaram os maiores valores, explicados por equação de terceiro grau. Nas demais, os valores foram significativamente inferiores, chegando novamente próximos de zero, com tendência quadrática. Para o índice de velocidade de emergência, quando as sementes foram armazenadas em sacos de pano, as variedades Pururuca Branco e Mato Grosso tiveram comportamento e valores muito semelhantes, sendo observada a menor redução ao longo dos seis meses de avaliação. A velocidade de formação de plântulas é um parâmetro importante na avaliação de sementes, visto que maior velocidade indica maior vigor e, assim, diminui o tempo de exposição aos patógenos, responsáveis pela deterioração das sementes (Bahry et al., 2006).

Para o comprimento de parte aérea, sob condições de casa de vegetação, quando as sementes foram armazenadas em embalagens plásticas (Figura 5), foram observados, ao final dos seis meses, valores próximos à condição inicial, com exceção da variedade Brancão. No armazenamento em sacos de pano, essa variável teve comportamento quadrático, com redução no segundo e quarto mês de avaliação e incremento no comprimento de parte aérea ao final do período, sendo este superior ao verificado na primeira avaliação. Azevedo et al. (2003), ao avaliarem a influência das embalagens e condições de armazenamento no vigor de sementes de gergelim, através do teste de comprimento de plântula, observaram que a condição de conservação (ambiente de laboratório e câmara seca), não apresentou diferenças significativas no vigor das sementes.

Para a variável massa seca de plântulas (Figura 6), nas sementes armazenadas em embalagens plásticas verificou-se tendência similar à observada na avaliação de comprimento de parte aérea, onde as variedades Caiano, Cabo Roxo e Bico de Ouro obtiveram os maiores valores e um pequeno incremento ao final do sexto mês de avaliação. A massa seca, para o armazenamento em sacos de pano, seguiu tendência quadrática, de modo geral, com pequena redução entre o segundo e o quarto mês de avaliação, apresentando incremento no sexto mês. Esses resultados não refletem o comportamento padrão das sementes armazenadas, quando se espera que, ao final do período de armazenamento, a avaliação de características das plântulas apresente decréscimo, ocasionado pela perda de vigor das sementes no decorrer do tempo. 
Caiano

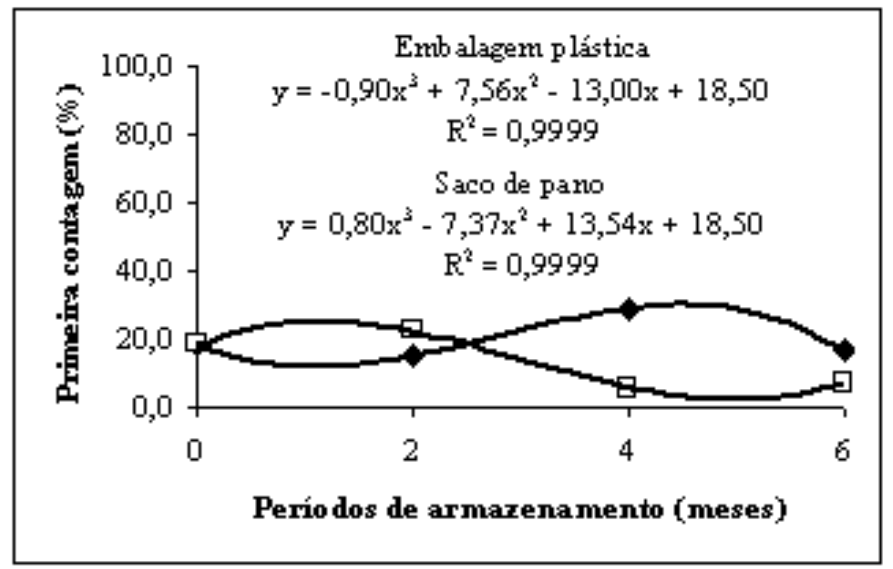

\section{Purutuca Branco}

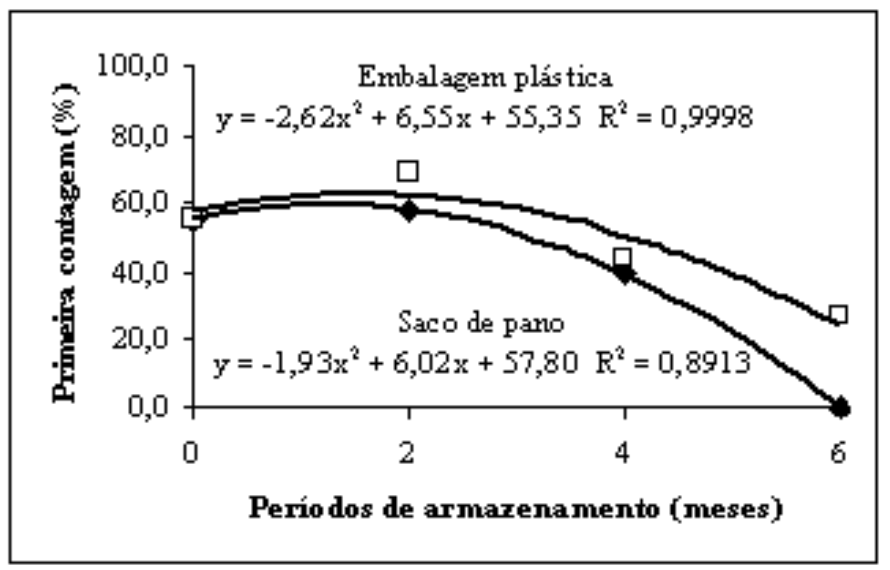

\section{Brancào}

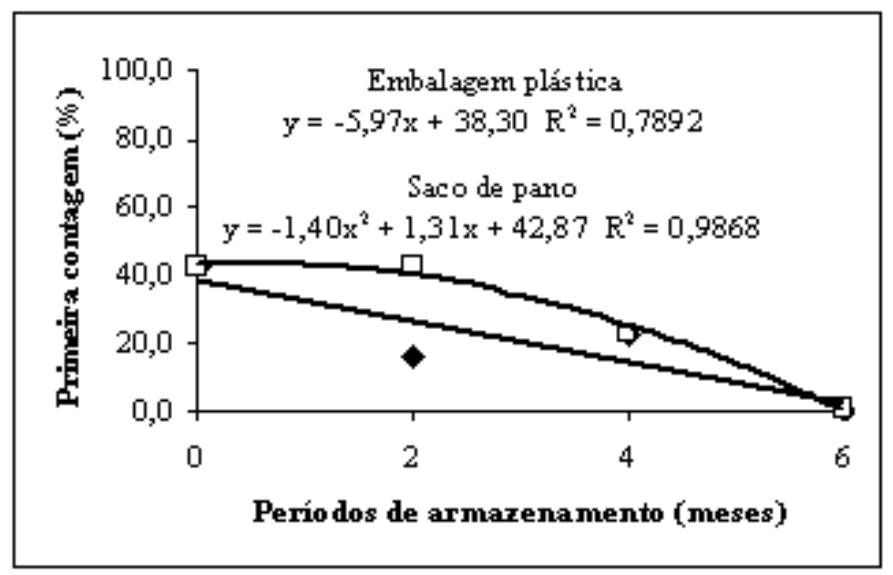

Mato Grosso

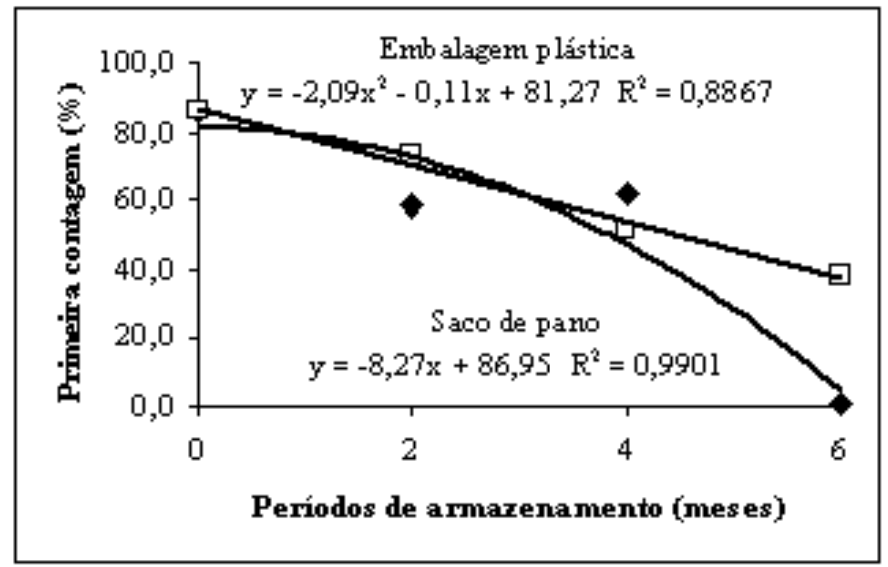

Cabo Roxo

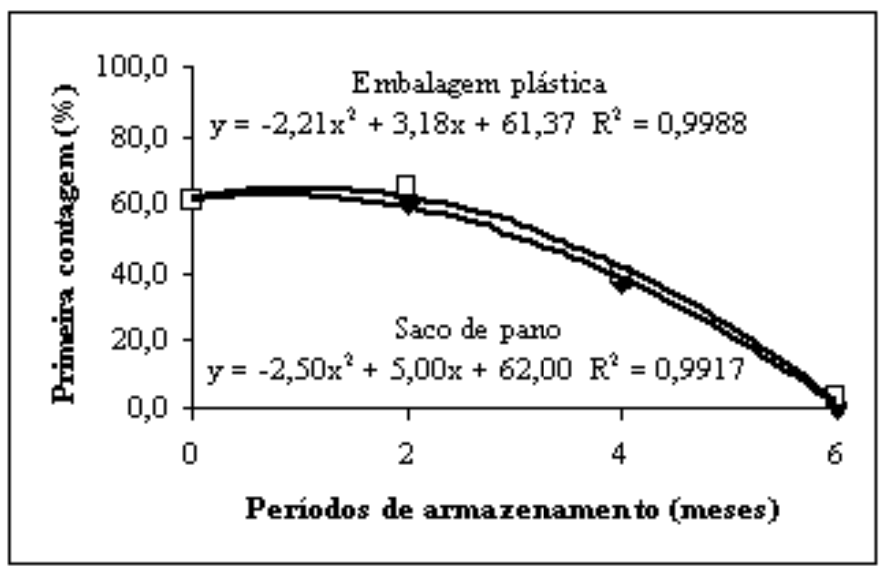

Bico de Outo

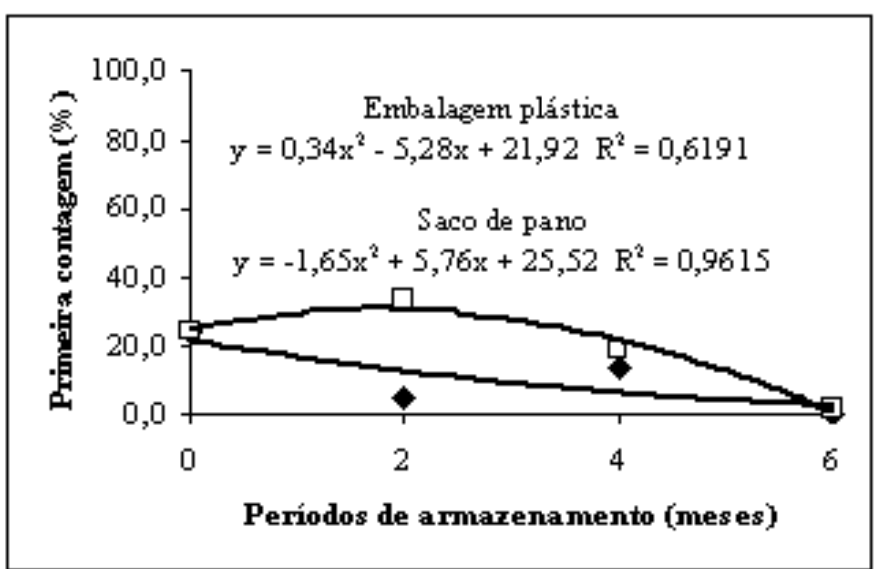

FIGURA 2. Resultados do período de armazenamento e primeira contagem de germinação de sementes de milho das variedades Caiano, Mato Grosso, Pururuca Branco, Cabo Roxo, Brancão e Bico de Ouro, acondicionadas em embalagem plástica (४) e em saco de pano ( $\square)$. 
Caiano

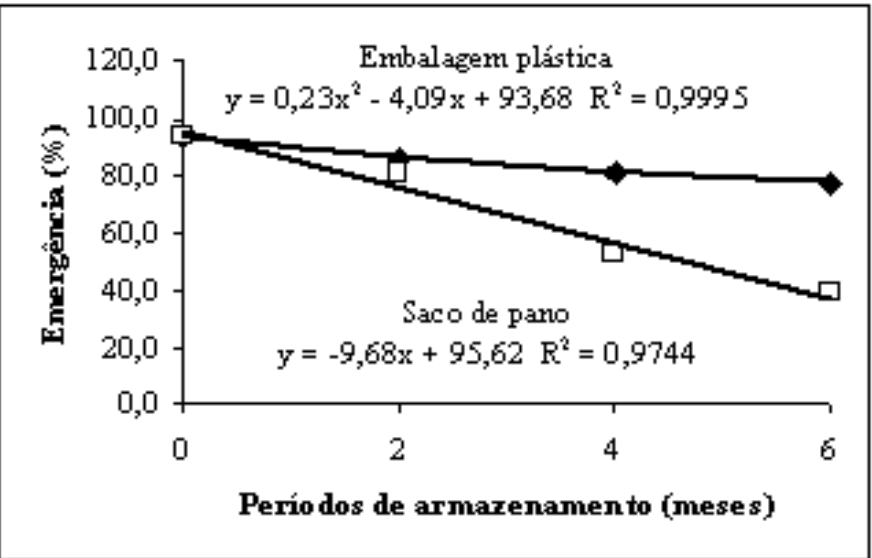

Furutuca Branco

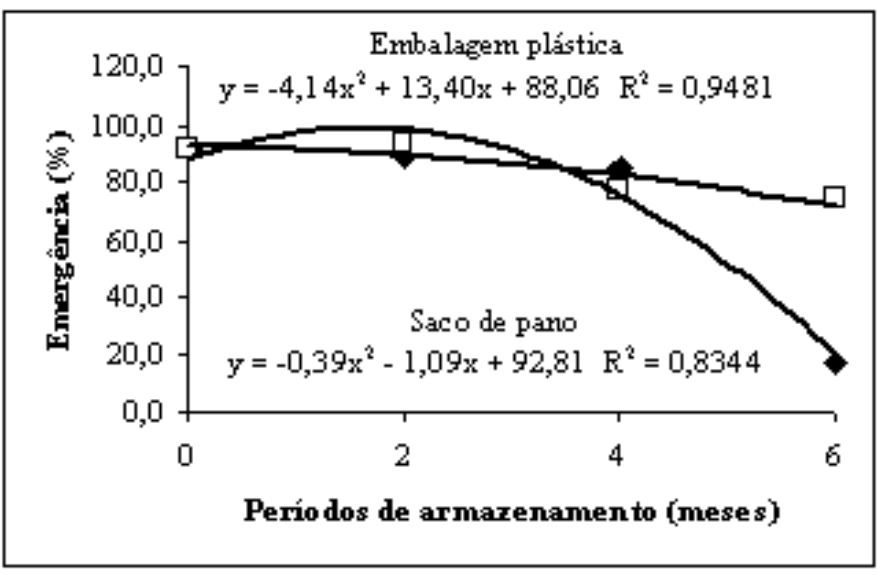

Brancão

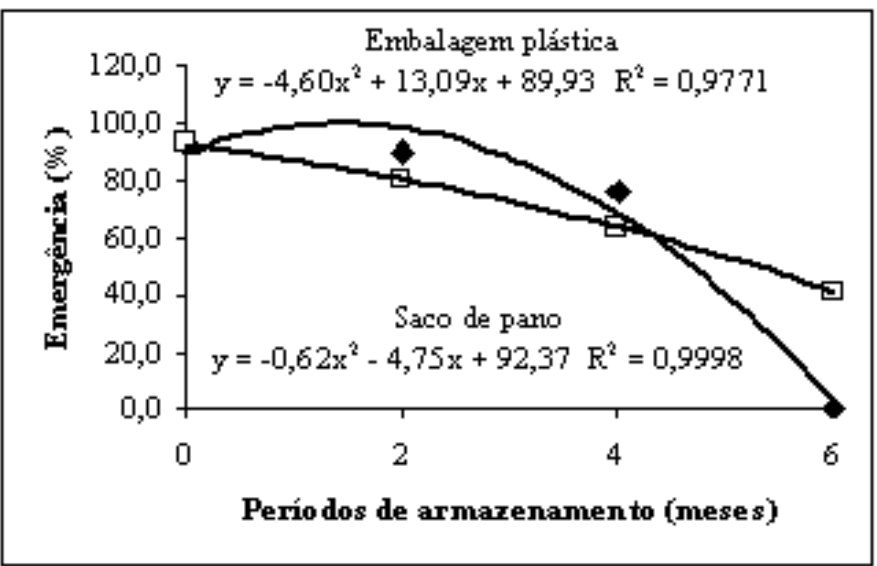

Mato Girosso

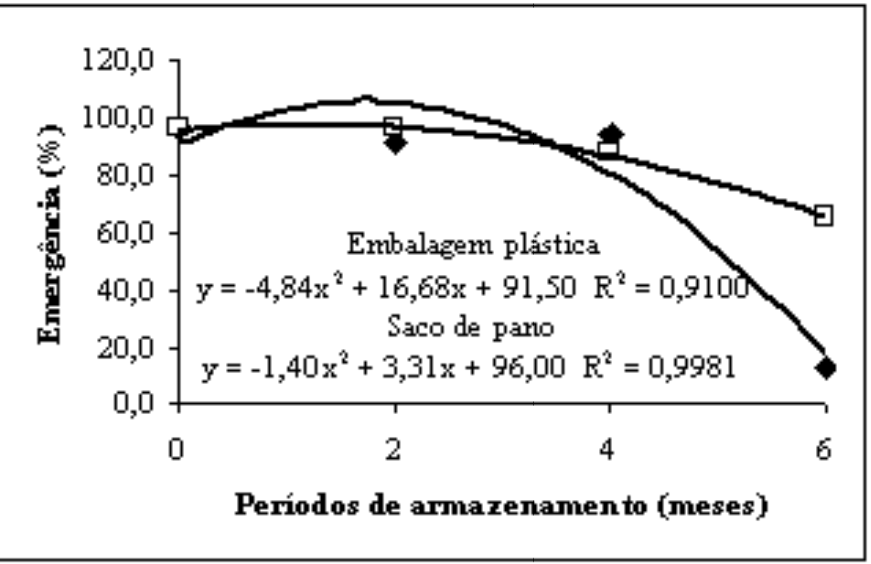

CaboRoxo

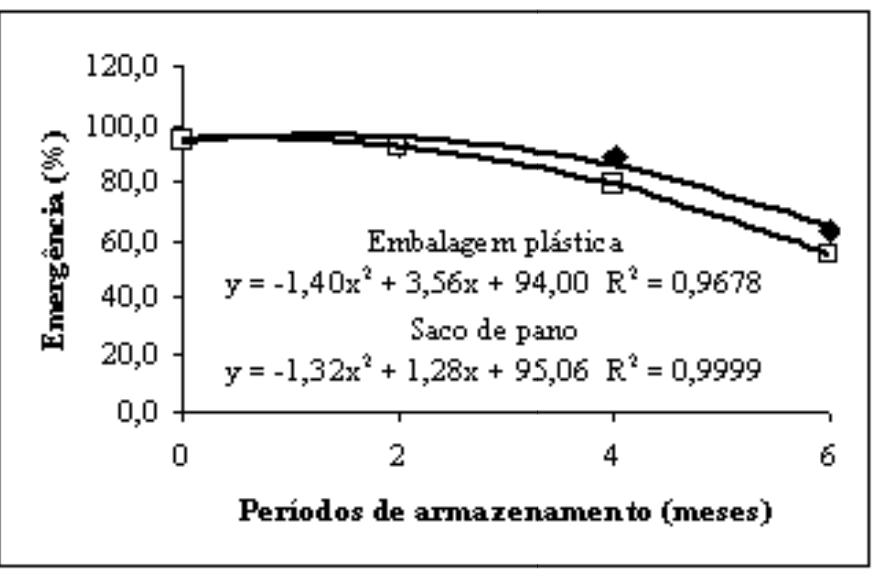

Bico de Ouro

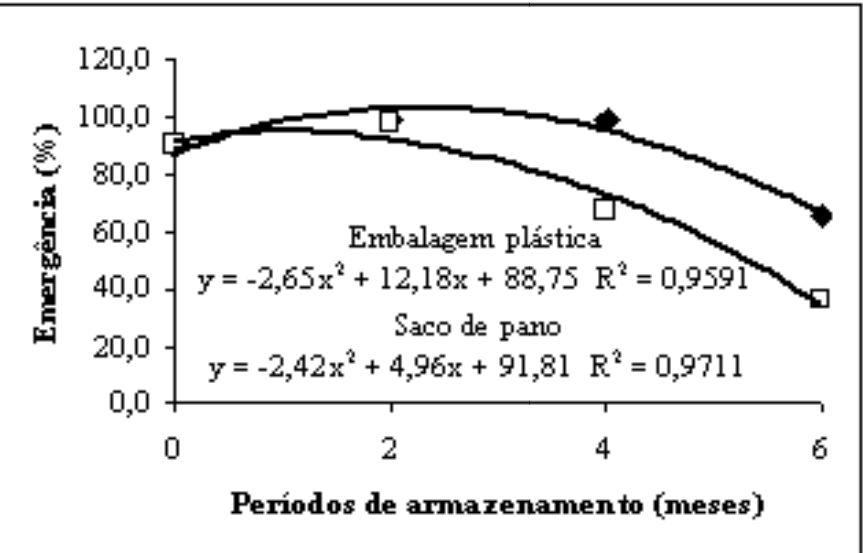

FIGURA 3. Emergência de plântulas de milho das variedades Caiano, Mato Grosso, Pururuca Branco, Cabo Roxo, Brancão e Bico de Ouro, obtidas de sementes acondicionadas em embalagem plástica (४) e em saco de pano ( $\square$ ) e armazenadas por seis meses. 
Caiano

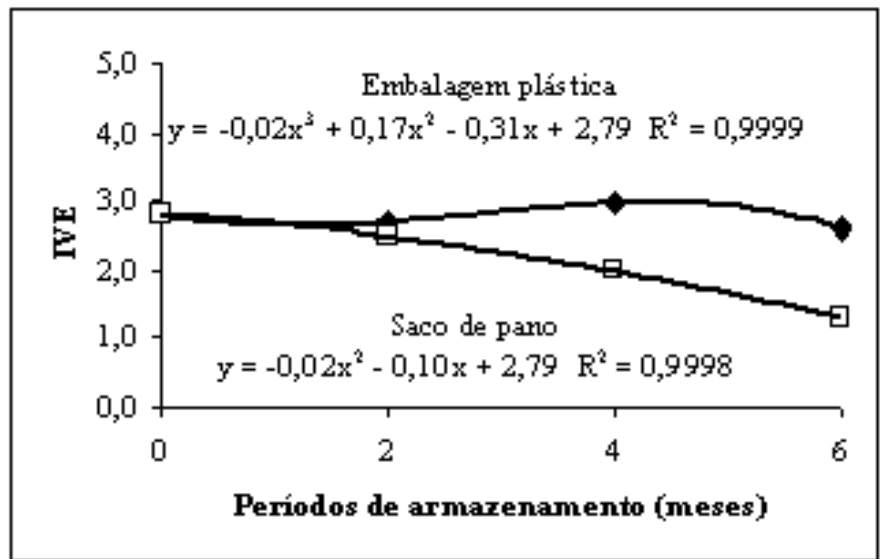

Furutuca Branco

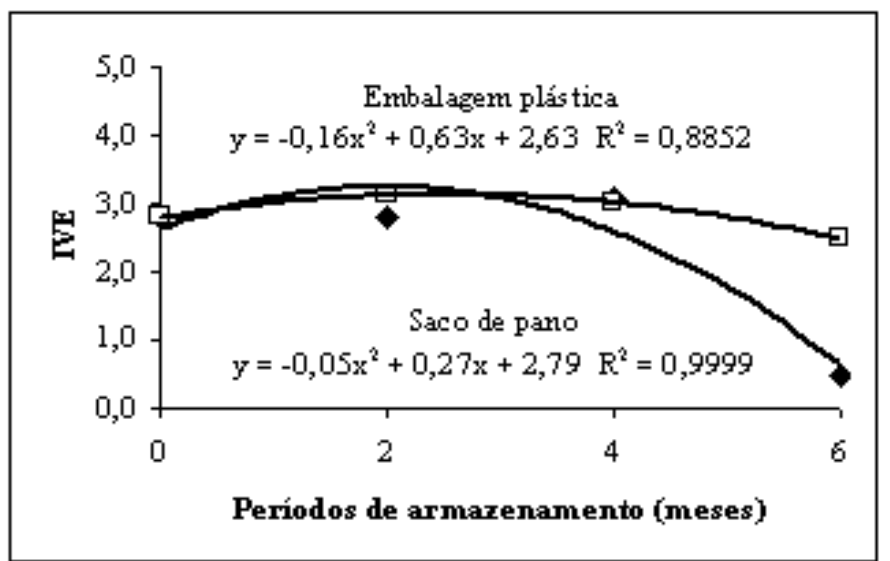

Brancão

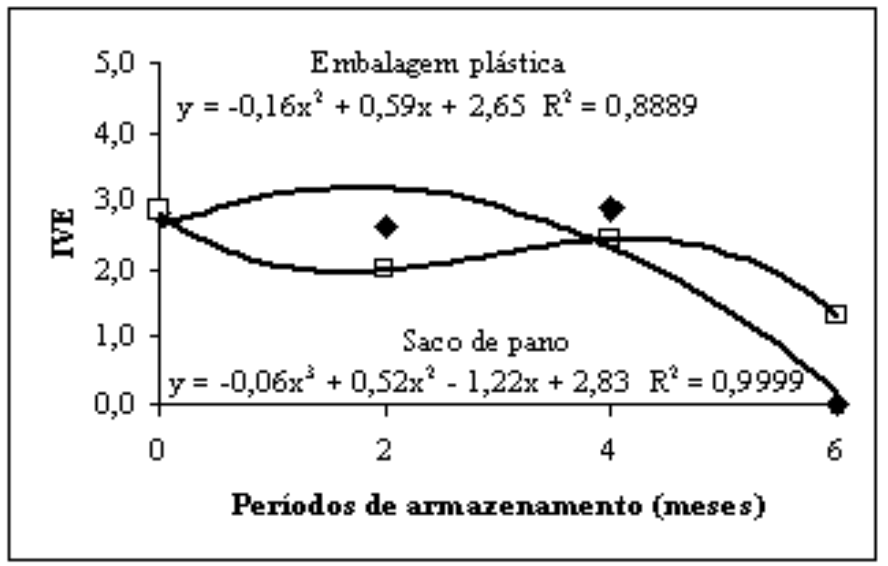

Mato Grosso

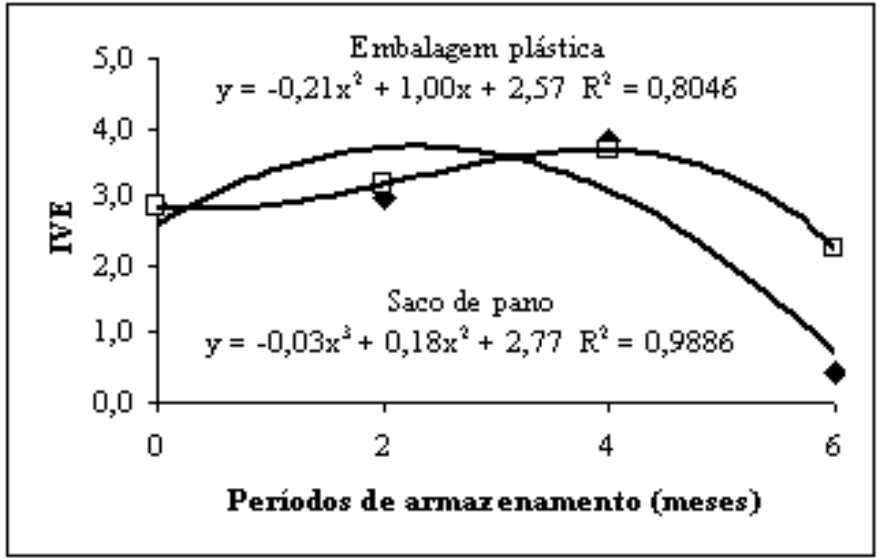

Cabo Roxo

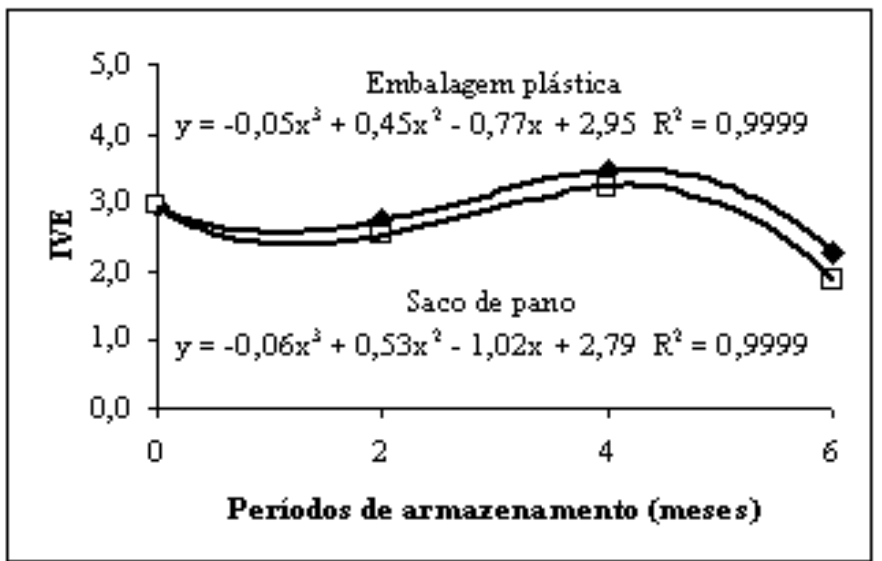

Bico de Onto

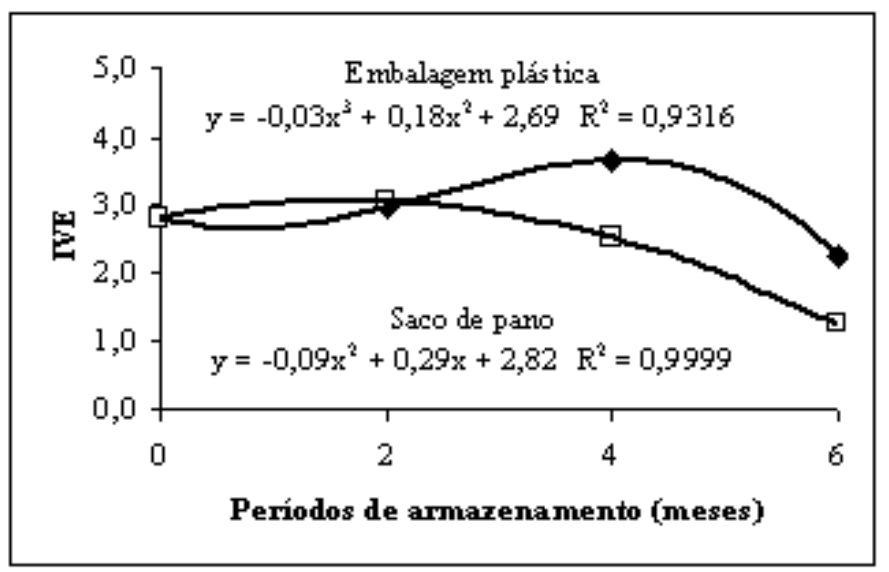

FIGURA 4. Índice de velocidade de emergência (IVE) de sementes de milho das variedades Caiano, Mato Grosso, Pururuca Branco, Cabo Roxo, Brancão e Bico de Ouro, acondicionadas em embalagem plástica ( $\diamond$ e em saco de pano ( $\square$ ) e armazenadas por seis meses 
Caiano

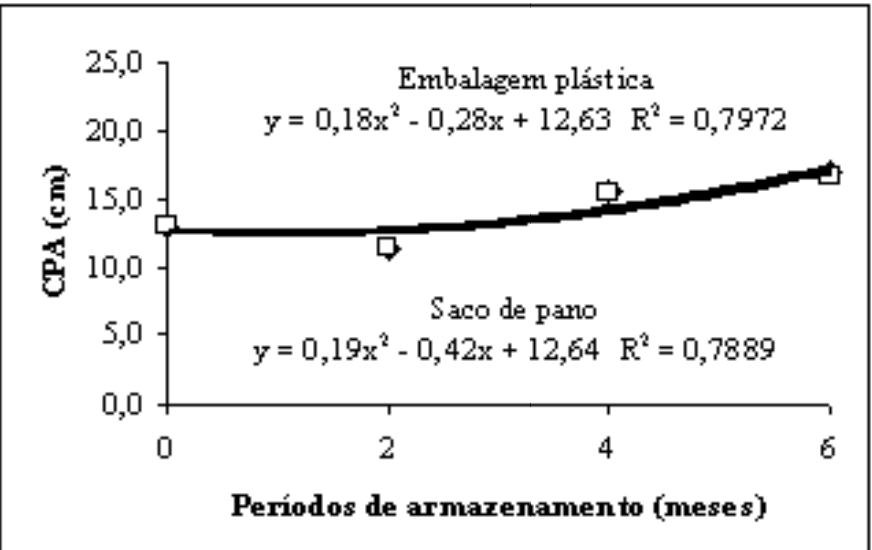

Furutuca Branco

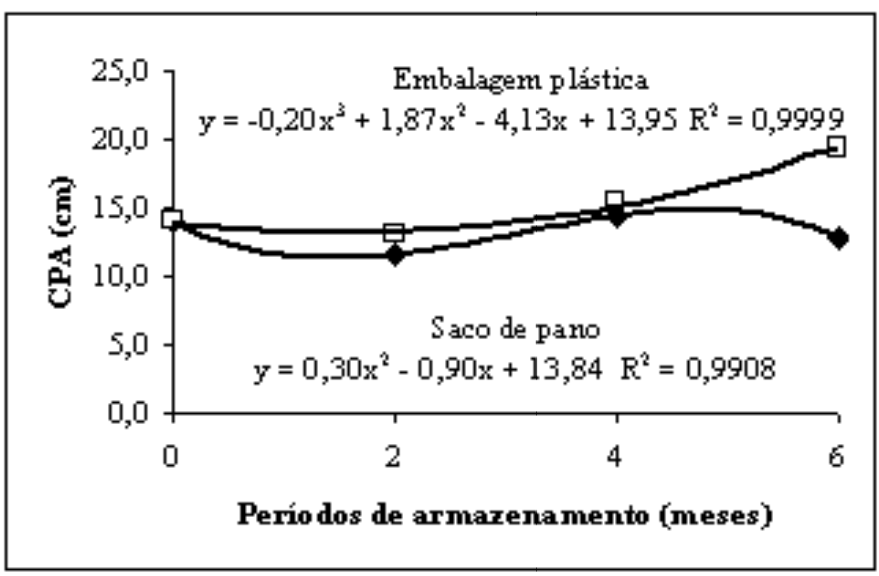

Brancão

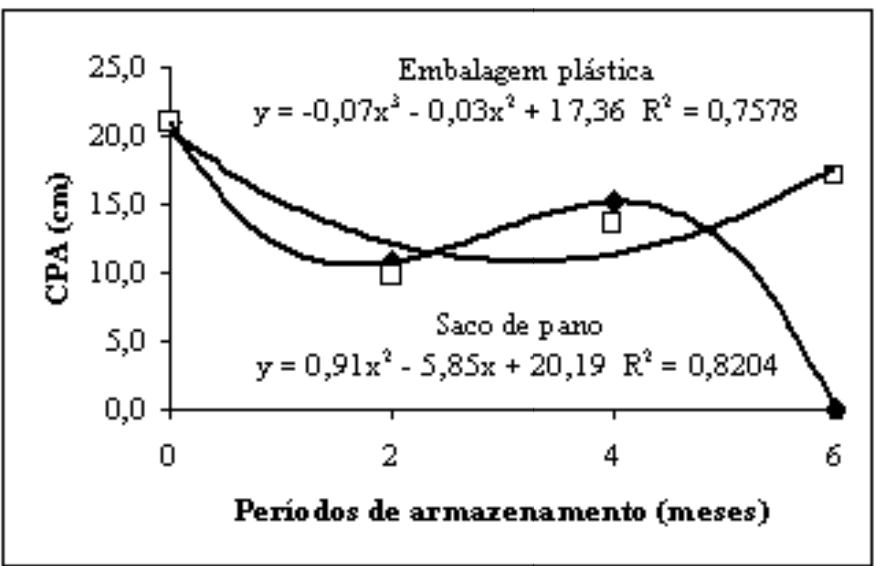

Mato Grosso

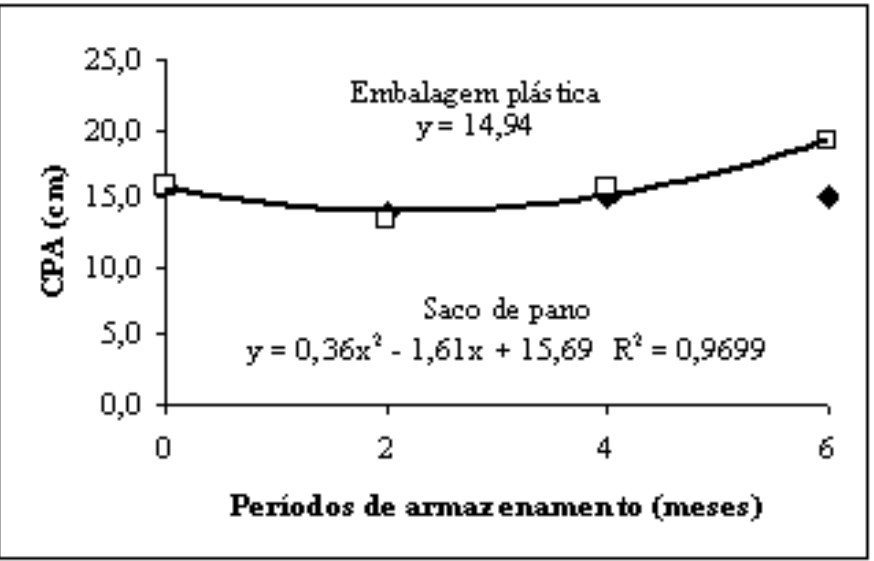

CaboRoko

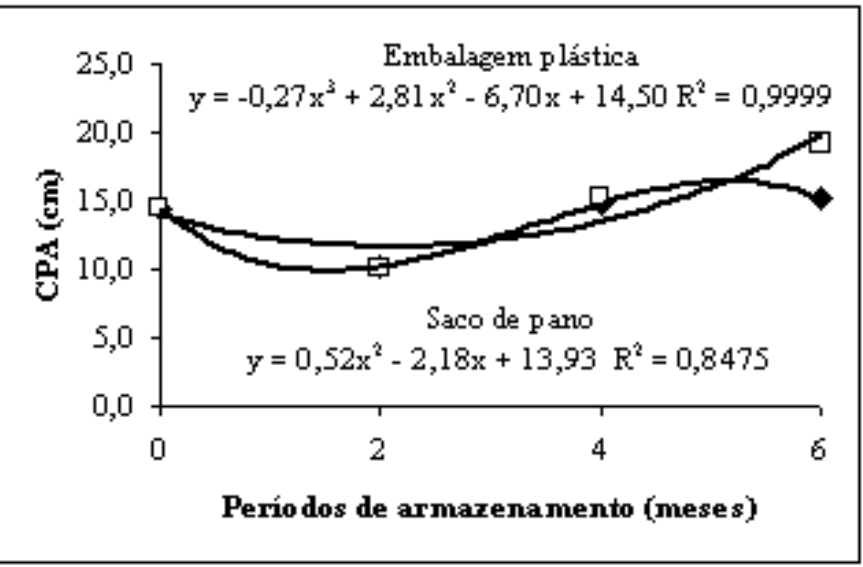

Bico de Orato

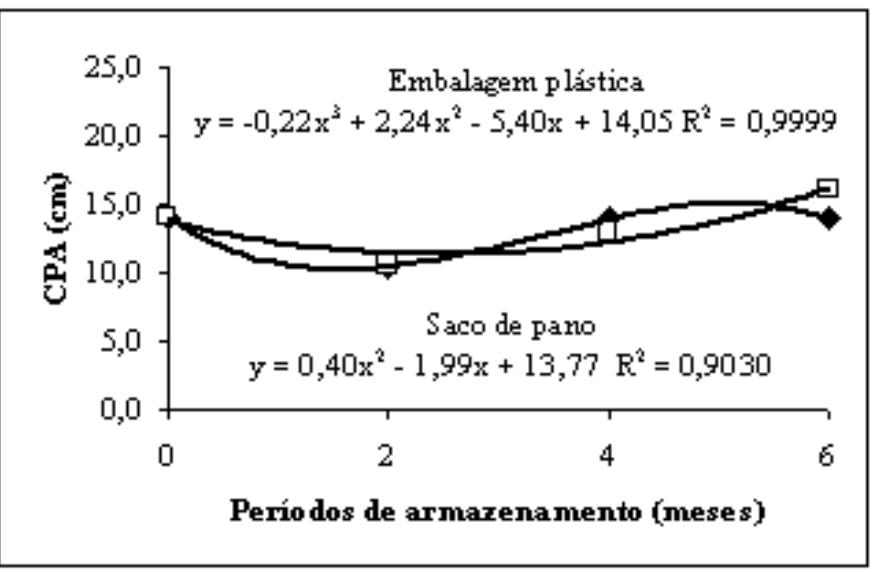

FIGURA 5. Comprimento de parte aérea (CPA) de plântulas oriundas de sementes de milho das variedades Caiano, Mato Grosso, Pururuca Branco, Cabo Roxo, Brancão e Bico de Ouro, acondicionadas em embalagem plástica $(\diamond)$ e em saco de pano $(\square)$ e armazenadas por seis meses. 
Caiano

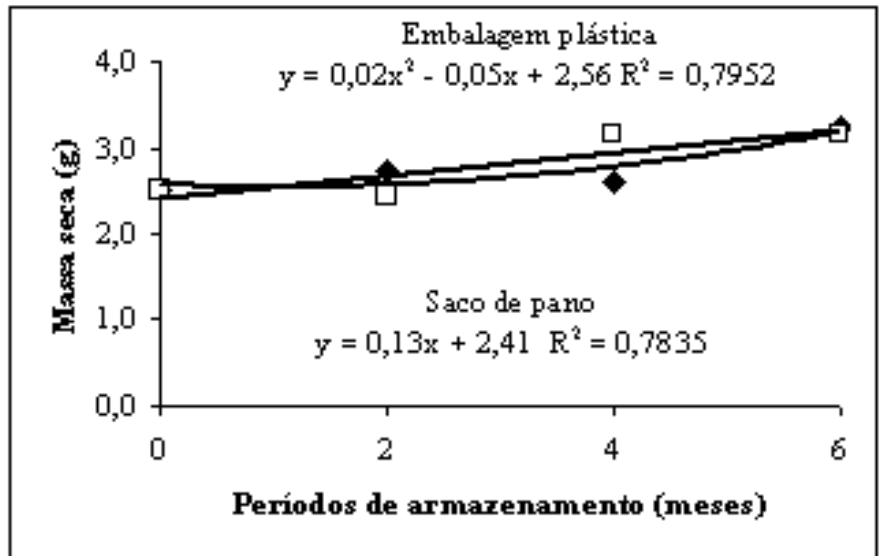

Futuruca Branco

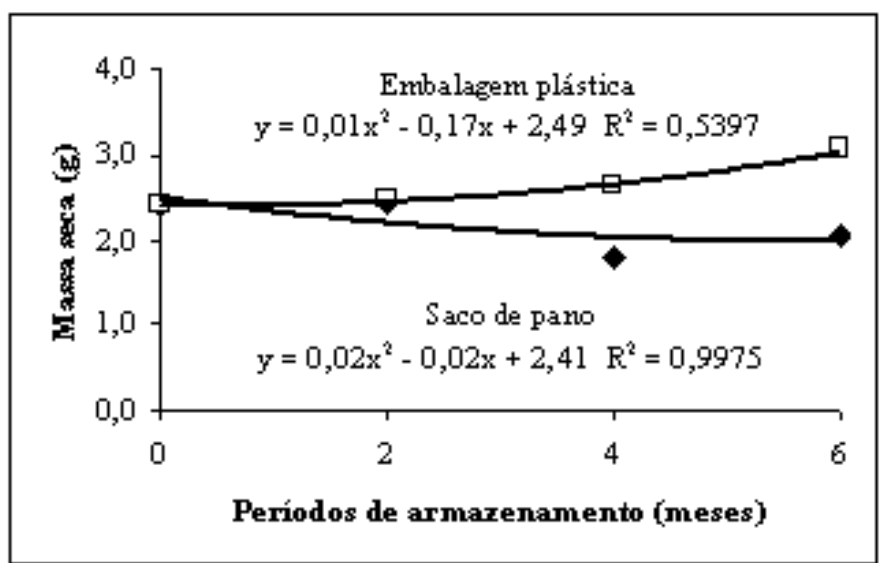

Brancão

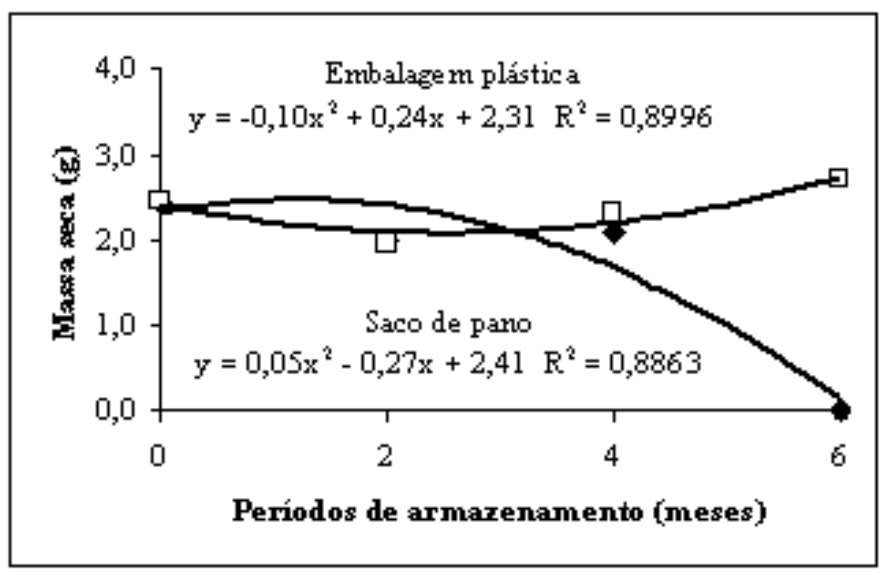

Mato Grosso

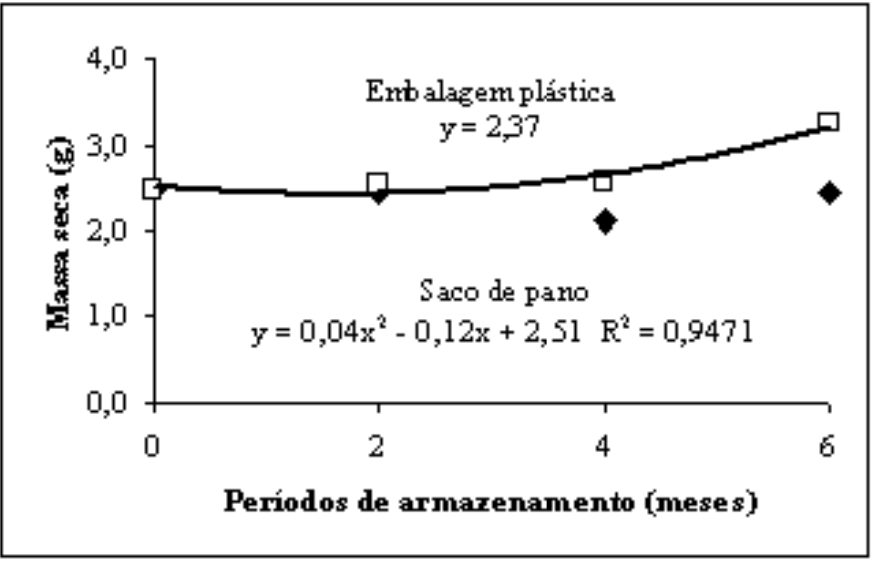

Cabo Roxo

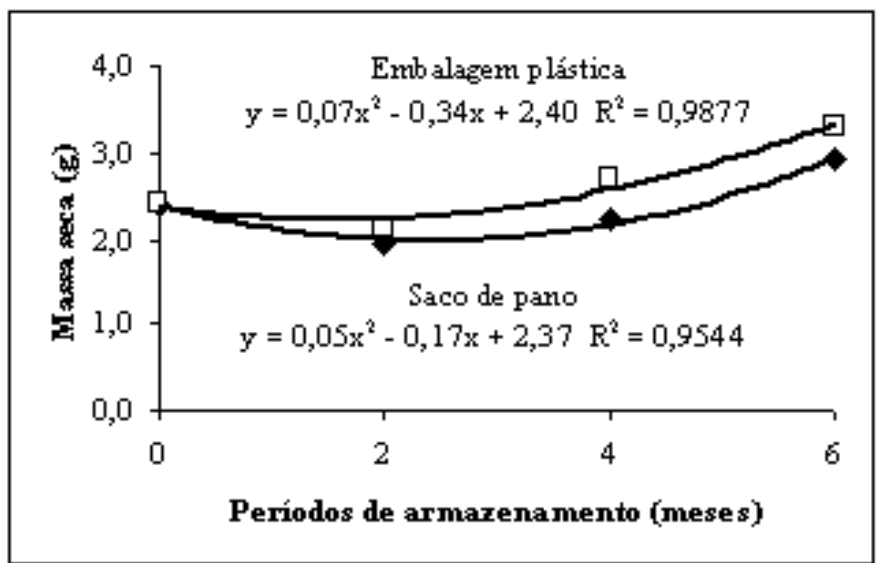

Bico de Outo

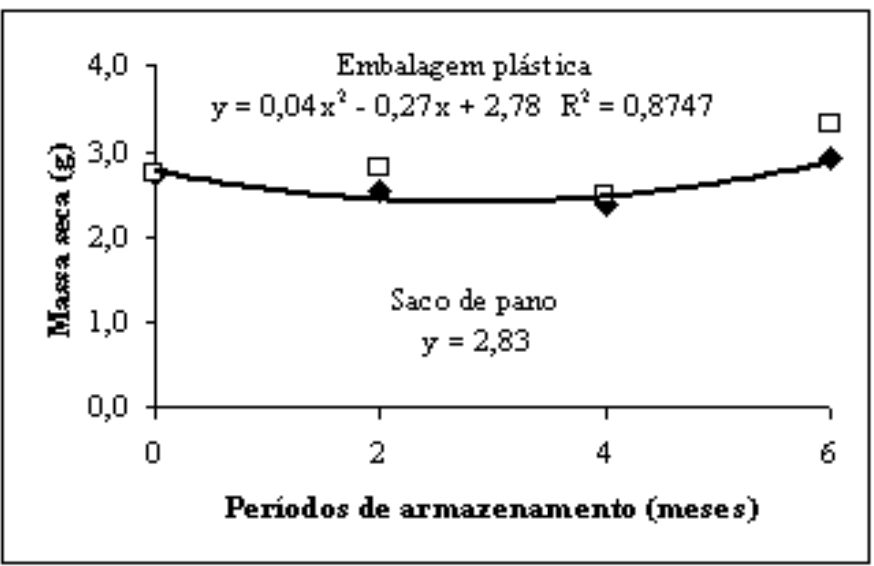

FIGURA 6. Massa seca de plântulas oriundas de sementes de milho das variedades Caiano, Mato Grosso, Pururuca Branco, Cabo Roxo, Brancão e Bico de Ouro, acondicionadas em embalagem plástica (४) e em saco de pano ( $\square$ ) e armazenadas por seis meses. 
Pode-se observar ao longo do período de armazenamento, comportamento distinto das variedades para cada embalagem em função da condição adversa, como a redução do oxigênio, pela condição de vácuo, ou o ataque de insetos praga. Para o armazenamento em embalagens plásticas, as variedades que mostraram melhor desempenho, de uma forma geral, foram Caiano, Cabo Roxo e Bico de Ouro, enquanto que para o armazenamento em sacos de pano, foram as variedades Pururuca Branco e Mato Grosso que tiveram melhor manutenção da qualidade fisiológica.

\section{CONCLUSÕES}

O comportamento das sementes durante o armazenamento, por 180 dias, depende da variedade e da embalagem utilizada.

Dependendo da cultivar, sementes de milho com teor de água de $13 \%$, acondicionadas em embalagens plásticas, mantêm sua qualidade fisiológica por 180 dias.

\section{REFERÊNCIAS}

ACOMPANHAMENTO da safra brasileira: grãos quarto levantamento janeiro de 2008, Brasília, DF: CONAB, 2007. $24 \mathrm{p}$.

ALMEIDA, F.A.C.; HARA, T.; CAVALCANTI MATA, M.E.R.M. Armazenamento de sementes nas propriedades rurais. Campina Grande: UFPB, 1997. 291p.

ARAÚJO, P.M.; NASS, L.L. Caracterização e avaliação de populações de milho crioulo. Scientia Agrícola, v.59, n.3, p.589-593, 2002.

AZEVEDO, M.R.Q.A; GOUVEIA, J.P.G.; TROVÃO, D.M.M.; QUEIROGA, V.P. Influência das embalagens e condições de armazenamento no vigor de sementes de gergelim. Revista Brasileira de Engenharia Agrícola e Ambiental, v.7, n.3, p.519-524, 2003.

BAHRY, C.A.; MUNIZ, M.F.B.; FRANZIN, S.M. Importância da qualidade fisiológica e sanitária de sementes de milheto para a implantação de pastagens. Santa Maria: CCR/UFSM, 2006. 4p. (Informe Técnico).

BAUDET, L. Armazenamento de Sementes. In: PESKE, S.T.; ROSENTHAL, M.D.; ROTA, G.M. (Ed.) Sementes: fundamentos científicos e tecnológicos. Pelotas: UFPel, 2003. p. $369-418$.

BILIA, D.A.C.; FANCELLI, A.L.; MARCOS FILHO, J. Comportamento de sementes de milho híbrido durante o armazenamento sob condições variáveis de temperatura e umidade relativa do ar. Scientia Agrícola, v.51, n.1, p.153157, 1994.

BRASIL. Ministério da Agricultura e Reforma Agrária. Secretaria Nacional de Defesa Agropecuária. Departamento Nacional de Produção Vegetal. Coordenação de Laboratório Vegetal. Regras para Análise de Sementes. Brasília, DF, 1992. 365 p.

CAMARGO, R.; CARVALHO, M.L.M. Armazenamento a vácuo de semente de milho doce. Revista Brasileira de Sementes, v.30, n.1, p.131- 139, 2008.

DELOUCHE, J.C; BASKIN, C.C. Accelarated aging techniques for predicting the relative storability of seed lots. Seed Science \& Technology, v.1, n.2, p.427-452, 1973.

MAGUIRE, J.D. Speed of germination - aid in selection evolution for seedling emergence and vigor. Crop Science, v.2, n.2, p.176-177, 1962.

MARCOS FILHO, J. Testes de vigor: importância e utilização. In: KRZYZANOWSKI, F. C.; VIEIRA, R. D.; FRANÇA NETO, J. B. (Ed.). Vigor de sementes: conceitos e testes. Londrina: ABRATES, 1999. p. 1-21.

MARINCEK, A. Qualidade de sementes de milho produzidas sob diferentes sistemas de manejo no campo e em pós-colheita. 2000. 105 f. Dissertação. (Mestrado em Fitotecnia) - Universidade Federal de Lavras, Lavras.

MARTINS, L.; LAGO, A.A. Conservação de semente de Cedrela fissilis: teor de água da semente e temperatura do ambiente. Revista Brasileira de Sementes, v.30, n.1, p.161167, 2008.

MORENO, J.A. Clima do Rio Grande do Sul. Porto Alegre: Secretaria da Agricultura, 1961. 41p.

NEW, J.H. Studies on vacum packing of seed. Seed Science \& Technology, v.16, p. 715-723, 1988.

PATERNIANI, E.; NASS, L.L.; SANTOS, M.X. O valor dos recursos genéticos de milho para o Brasil: uma abordagem histórica da utilização do germoplasma. In: UDRY, C.W.; DUARTE, W. (Org.). Uma história brasileira do milho: o valor dos recursos genéticos. Brasília, DF: Paralelo 15, 2000. p.11-41.

PORTELLA, J.A.; EICHELBERGER, L. Secagem de grãos. In: Conceito de secagem. Passo Fundo: Embrapa Trigo, 2001. p. 27-29.

PRATES, H.S.; FRATTINI, J.A. Principais pragas dos grãos armazenados e recomendações para seu controle. Campinas: CATI, 1976. 26p. (CATT. Boletim Técnico, 89).

SMITH, M.T.; BERJAK, P. Deteriorative changes associated 
with the los viability of stored desications of seed associated Mycroflora during atorage. In: JAIME, K.; GALILI, G. Seed development and germination. New York: Basel-Hang Young, 1995. p.701-746.
VIEIRA, R.D.; CARVALHO, N.M. Testes de vigor em sementes. Jaboticabal: FUNEP, 1994. 164p.

ZONTA, E.P.; MACHADO, A.A. Sistema de Análise Estatística para Microcomputadores - SANEST. Pelotas: UFPel, 1984. 75p 